\title{
CARNAVAL DO MEIO-NORTE BRASILEIRO A NOVA DINÂMICA DA FESTA E A RETRAÇÃO DAS ESCOLAS DE SAMBA EM SÃO LUÍS, BELÉM E TERESINA
}

Eugênio Araújo (UFMA)

O início da pesquisa foi motivado pela verificação do desaparecimento e diminuição de muitas agremiações em São Luís do Maranhão, fenômeno depois percebido também no interior do estado e capitais vizinhas. $O$ presente artigo verifica a dinâmica cultural desses grupos nas cidades de Belém e Teresina, sob perspectiva histórica comparativa e relacional em que entram ingredientes como influência e resistência cultural; criação, disseminação e adaptação de modelos festivos; contribuição do turismo, manipulação das identidades culturais, organização sociopolítica das agremiações e atuação dos órgãos públicos de cultura.

ESCOLA DE SAMBA, DINÂMICA CULTURAL, CARNAVAL.

FERREIRA, Antônio Eugênio Araújo. Carnaval do meio-norte brasileiro: a nova dinâmica da festa e a retração das escolas de samba em São Luís, Belém e Teresina. Textos escolhidos de cultura e arte populares, Rio de Janeiro, v.9, n.1, p. 77-98, mai. 2012. 


\title{
CARNAVAL IN THE BRAZILIAN MIDDLE-NORTH
}

THE NEW DYNAMICS OF THE PARTY AND THE RETRACTION OF SAMBA SCHOOLS IN SÃO LUIS, BELÉM AND TERESINA

\author{
Antônio Eugênio Araújo Ferreira (UFMA)
}

This research was motivated by the disappearance and decline of many carnival associations in São Luis do Maranhão, a phenomenon later perceived inland and in neighboring capitals. This article examines the cultural dynamics of these groups in the cities of Belém and Teresina, under a comparative and relational historical perspective which involves elements such as influence and cultural resistance, creation, dissemination and adaptation of festive models; the contribution of tourism, manipulation of cultural identities, sociopolitical organization of the associations and actions of public institutions of culture.

SAMBA SCHOOLS, CULTURAL DYNAMIC, CARNIVAL.

FERREIRA, Antônio Eugênio Araújo. Carnaval do meio-norte brasileiro: a nova dinâmica da festa e a retração das escolas de samba em São Luís, Belém e Teresina. Textos escolhidos de cultura e arte populares, Rio de Janeiro, v.9, n.1, p. 77-98, mai. 2012. 


\section{O CARNAVAL DE SÃO LUÍS}

Já há algum tempo venho tentando pensar o carnaval brasileiro de maneira mais abrangente e ultrapassar as fronteiras aparentemente rígidas traçadas pelos vários modelos de festa existentes no país. A primeira tentativa concretizou-se com uma pesquisa sobre o carnaval maranhense, verificando as vicissitudes da transposição do modelo de carnaval carioca para São Luís, no Maranhão, concentrado nas escolas de samba locais (ARAúJo, 2001). Logo pude observar a complexidade e implicações de tal processo; durante todo o tempo tive que recorrer ao cotejamento com aquilo que se dava na cidade do Rio de Janeiro, centro irradiador desse modelo de carnaval e da maioria dos estudos feitos até então sobre o tema, publicada pelas grandes editoras. A influência carioca dava-se portanto em duas vertentes: por um lado, no modelo de festa em si (que impressiona artistas, foliões e grupos carnavalescos) e, por outro, na forma de estudá-la e legitimá-la perante a sociedade (que diz respeito aos intelectuais, aos agentes financiadores, às políticas públicas) e comercializá-la (área da iniciativa privada, do comércio, da indústria do carnaval, etc.). Minha dissertação de mestrado pode ser definida como um estudo sobre a influência (prática e teórica) do carnaval carioca em uma capital do Nordeste. A partir de então comecei a observar a dinâmica da festa carnavalesca em outras cidades, em uma perspectiva relacional e comparativa, que me levou a incluir estudos ali realizados. Assim, ainda estou ampliando cautelosamente o campo prático e teórico da pesquisa, mantendo o Rio de Janeiro como importante referência, mas já não a única e, em alguns casos, já não a mais determinante, pois o que me despertou para o tema não foi a simples constatação da influência carioca, mas, pelo contrário, a percepção da vontade de sua negação.

As escolas de samba de São Luís sofreram, de finais dos anos 80 até inícios da década de 2000, intensa campanha de desprestígio com consequente desestruturação e desaparecimento da maioria delas. A partir da adoção do modelo carioca de desfile, o carnaval ludovicense assumiu dinâmica marcada pela rápida criação e extinção de muitos grupos e eventos carnavalescos: desapareceram muitas escolas e blocos de enredo, os bailes de clubes e desfiles de fantasias; criaram-se cordões, blocos e outras manifestações de rua, etc. Segundo alguns observadores a festa teria sofrido um processo de empobrecimento; outros dizem que, na verdade, ela recuperou fôlego, ultrapassando uma fase marcada pela simples "imitação malsucedida do modelo carioca".

Não compartilho exatamente dessas posições antagônicas, pois estou cada vez mais convicto de que as formas culturais são absolutamente 
dependentes da estrutura social que as engendram: mudando tal estrutura, elas também mudam. O carnaval de São Luís mudou não só devido à adoção do modelo carioca, mas porque a mudança é inevitável em uma cidade que cresce. No entanto, a manipulação consciente e teleológica de alguns processos de reforma não pode ser ignorada.

A transformação da cidade em polo turístico (projeto político do governo estadual) passa a determinar outra dinâmica cultural. São Luís precisa criar, então, identidade cultural única e irrepetível, dentro do contexto nacional, buscando no regionalismo exótico o principal esteio - algumas manifestações foram consideradas mais indicadas para isso (o bumba meu boi), enquanto outras foram "desestimuladas" (escolas de samba) porque não se encaixam bem no processo de construção de uma identidade cultural específica. Até a década de 1980, o crescimento do carnaval em São Luís foi denotado pelas escolas de samba, que respondiam ao anseio de mais organização e sofisticação de várias camadas urbanas: negros e mestiços em busca de visibilidade positiva, classe média em busca de diversão e aproximação de modelos dos centros mais desenvolvidos, etc. Depois, o modelo carioca foi considerado usurpador, pelos artistas e investidores locais, suscitando um movimento de reação cultural fortemente entranhado em tradições passadas, uma espécie de revival, redirecionando a festa para cunho mais regional. Nesse processo, se muitos grupos desapareceram, outros foram criados. Numa espécie de darwinismo cultural, só uma minoria conseguiu perdurar - os mais fortes, bem estruturados e com maior inserção na estrutura social abrangente, que inclui simpatizantes, financiadores e "padrinhos" bem colocados.

Na década de 1990, o carnaval de São Luís passou por remodelação, e havia uma espécie de acordo entre os agentes remodeladores (órgãos de cultura do estado/município, grupos empresariais, mídia e artistas) sobre a exclusão das escolas de samba desse "novo carnaval" - consideradas "imitações malfeitas" do modelo carioca, elas estariam desvirtuando a festa maranhense e foram conclamadas a virar blocos ou simplesmente a encerrar suas atividades. A política cultural regionalista já tinha eleito o bumba meu boi como principal produto cultural do estado, mas, em se tratando de um folguedo junino, era preciso encontrar algo análogo para o período carnavalesco, e as escolas de samba não se encaixavam bem na proposta. A saída foi então estimular o "carnaval de rua", a exemplo do que acontecia em Salvador, Recife e Olinda. A própria semelhança arquitetônica entre São Luís e essas cidades estimulou as identificações, corroboradas pelos discursos oficiais. ${ }^{1}$ 
Paralelo à postura estatal, é preciso considerar também o papel dos artistas que, professando o discurso do regionalismo, conseguiram engendrar novas formas culturais ou "reviver" (termo muito usado em São Luís) outras, determinando em parte, os novos rumos do carnaval da cidade. Dentro de cada brincadeira, surgem agentes especialistas em estratégias de inserção em um mercado de produção e consumo cultural cada vez mais competitivo, mas no qual os patrocinadores ainda são escassos - o Estado continua sendo o maior investidor da festa. É uma teia complexa de interesses, afirmação étnicoidentitária e classista. Em São Luís, o campo carnavalesco é um bom exemplo de como isso vem acontecendo.

Lá, o dinheiro antes investido no carnaval e nas escolas de samba migrou para o São João e para os grupos folclóricos, especialmente os de bumba meu boi. Agentes culturais antes envolvidos com as escolas passaram a organizar folguedos juninos como forma de obter acesso aos recursos públicos e ao reconhecimento da mídia.

As escolas de samba eram brincadeiras muito valorizadas pela população, mas a partir de meados da década de 1980, elas começaram a atravessar seguidos períodos de crise; inicialmente o fenômeno foi interpretado, tanto por foliões quanto por observadores, como consequência da insuficiência econômica que geraria insuficiência estética: primeiro desapareceram as menores e mais pobres. Sambistas e cronistas interpretaram o fato como consequência da "carioquização" do samba maranhense, ou seja, a tentativa de fazer desfiles semelhantes aos cariocas:

Não dava mais pra tentar imitar as escolas de samba cariocas. Dinheiro curto e despesas cada vez maiores. Só nos deu prejuízo a carioquização das nossas escolas de samba, já que a gente tinha até que tirar empréstimo pra montagem do samba-enredo... Quem vê prejuízo em tudo por tudo e ainda continua batendo a cabeça no erro? ${ }^{2}$

Notar o realce dado pelo dirigente à dimensão econômica da manifestação, com a estratégia do empréstimo e a ideia de prejuízo - uma dimensão interessante para este trabalho, que pretende ver a escola de samba não apenas como uma "manifestação popular", mas também como produto viável do mercado de entretenimento carnavalesco, em concorrência com outros, como blocos de diversos tipos, trios elétricos e outras manifestações.

Quando o processo de enfraquecimento chegou às grandes e antigas agremiações, ameaçando mesmo as mais ricas, desenhou-se um quadro mais grave. Ficou claro que a política oficial local trabalhava pela extinção das escolas 
de samba ou, pelo menos, por sua "transformação" em "blocos populares" que de alguma forma "traduzissem mais a alma do povo maranhense". Tal situação atingiu o ápice em meados da década de 1990, quando a estratégia dos grupos detratores (ataque midiático e corte de subvenção) surtiu efeito: o desaparecimento de muitas escolas enfraqueceu o movimento sambista organizado e suas possíveis ações em conjunto. ${ }^{3}$ No início da década de 1980, havia em São Luís três grupos de desfile, totalizando quase 30 escolas de samba. As maiores, como a Turma do Quinto e a Flor do Samba, chegavam a desfilar com mais de três mil componentes. A partir de 1995, quando apenas nove escolas desfilaram, sobrou apenas o Grupo 1. Na pior fase, apenas sete escolas desfilavam em uma passarela improvisada (a prefeitura deixou de construí-la), nenhuma chegando a ter mil desfilantes. Tal fenômeno repetiu-se no interior do estado, onde muitas cidades que também promoviam desfiles de escolas de samba viram suas agremiações desaparecerem, substituídas por trios elétricos e blocos de todos os tipos.

Ao mesmo tempo São Luís tornava-se nacionalmente conhecida como a cidade do "bumba meu boi" (movimento de "resgate" e valorização do folclore) e do "reggae", esse presente desde a década de 1970, encampado pela mídia e pelo movimento negro. Em 1993 começa a promover seu carnaval fora de época, o Marafolia. Bumba meu boi, reggae e micareta são boas oportunidades de diversão de massa, afirmação de discurso identitários e lucro para as classes populares.

A "reforma" do carnaval de São Luís foi orientada pela ideia de "maranhensidade", com a criação de circuitos carnavalescos, reocupação do centro histórico e criação de muitas brincadeiras cujo mote é "reviver" os carnavais antigos e recuperar a identidade local. As escolas de samba resistiram - depois de um movimento mais ou menos organizado. Sobraram cerca de dez agremiações, e hoje elas conseguem apresentar um desfile que continua atraindo público especificamente interessado: a noite de desfile das escolas é a mais frequentada nas arquibancadas da passarela do samba, que voltou a ser montada e financiada pelo poder público.

\section{MODELOS DA FESTA, SUAS VARIAÇÕES, SEU CARÁTER AGONÍSTICO}

Decerto cada região e/ou cidade tem sua própria forma de produzir e brincar o carnaval, mas essa aparente "variedade infinita" pode mascarar um sentido de unidade subjacente, mais ou menos disfarçado por polaridades redutoras. Nas últimas décadas acirrou-se no Brasil a contenta entre dois 
modelos distintos de festa carnavalesca, que disputam a preferência dos foliões brasileiros e estrangeiros: o modelo carioca e o modelo baiano, que correspondem, em tese, à dicotomia clássica entre apolíneo e dionisíaco (RECTOR, in: ECO, 1989).

O carnaval carioca classificado como festa apolínea, aposta nos desfiles suntuosos de grupos autodenominados "escolas de samba", que participam de um concurso estético-esportivo com alto teor dramático-narrativo. Cada escola de samba apresenta um tema-enredo que suscita discussões e críticas, desenvolvido dentro da visão particular de cada carnavalesco (profissional responsável pela concepção estética do grupo). As escolas maiores desfilam em uma passarela-monumento construída especialmente para o evento, no centro da cidade. Todas estão submetidas a regulamentos e julgamentos mais ou menos rígidos, com a proclamação de vencedores e perdedores, e consequentes ritos de ascensão e rebaixamento anuais que determinam a dinâmica da mobilidade hierárquica das escolas entre os vários "grupos" existentes, a saber: partindo do Grupo Especial (mais rico e visível), passando pelos Grupos Rio de Janeiro 1, 2, 3 e 4 (antigos Grupos de Acesso), em gradação descendente de economia, estética e visibilidade midiática. A maior atração do carnaval carioca é o desfile das escolas de samba do Grupo Especial, ao qual o público pagante assiste acomodado em grandes arquibancadas de concreto. Conforme decai a hierarquia diminuem o público e a participação geral, sendo que as menores escolas desfilam hoje em Campinho, bairro próximo a Madureira, Zona Norte da cidade (até 2002, o desfile também era feito na região central da cidade, Av. Rio Branco). Mas as escolas de samba não esgotam o carnaval carioca, que possui muitas outras manifestações: blocos de rua, bandas, blocos de clóvis, bailes de clubes, etc. No entanto, o processo de comunicação midiática hoje privilegia a divulgação das escolas de samba, cujo desfile é transmitido ao vivo para todo o país pela Rede Globo, impressionando sambistas desde a década de 1970. Mesmo antes disso, as escolas cariocas já eram referência para todas as outras espalhadas pelo país. Depois das transmissões via tevê, a comparação cabal das imagens começou a gerar insatisfações nas cidades que tentavam implementar um carnaval sambista análogo ao carioca. O limite econômico e estético foi sentido em muitas localidades, contribuindo para os afastamentos.

O carnaval soteropolitano, classificado como dionisíaco, concentrase na brincadeira, no prazer do canto e da dança, em que blocos e artistas se apresentam sem clara estrutura dramático-narrativa, sem concurso e sem ganhadores e perdedores oficialmente declarados. Os grupos baianos desfilam e/ou concentram-se em ruas e praças de alguns trechos escolhidos 
da cidade (centro histórico, região praieira próxima ao Centro), determinando "circuitos carnavalescos" mapeados e preparados especialmente para a festa. As principais atrações são os blocos de trio, associação de cantores e bandas de sucesso com proprietários dos trios elétricos, enormes carros de som equipados como palcos móveis, que desfilam pela cidade, seguidos a pé pelos foliões. Enquanto os músicos apresentam seus shows sobre o trio em movimento, os foliões pagantes que portam uma fantasia sumária (abadá) podem cantar e dançar dentro do espaço delimitado pela corda e pelos cordeiros (seguranças que carregam a corda), restringindo o acesso junto ao trio, que também conta com bares e banheiros ambulantes. Fora desse espaço, está a multidão maior, de não pagantes, que também brinca, observando, cantando e dançando durante a passagem dos trios que se sucedem no desfile - embora os baianos resistam à "espetacularização" da festa, arquibancadas e camarotes são montados ao longo dos trajetos dos trios, nos chamados "circuitos". A cidade de Salvador é dividida em vários deles, cada um com características marcadas: mais ou menos caro, lotado, perigoso, tranquilo, transgressor, etc. O circuito do Campo Grande, no centro histórico, é o mais antigo e tradicional, e nele o direito de desfilar é dado pela antiguidade das agremiações; no Pelourinho o circuito é "mais calmo", ideal para crianças e terceira idade; o circuito da orla (Barra/Ondina) é a alternativa para os trios novatos. O sucesso dos grupos é medido pelo retorno comercial e financeiro, mas também em Salvador, blocos de trio não esgotam a festa - existem muitos outros tipos de manifestações do carnaval baiano: blocos afro, alternativos, bandas, afoxés, concursos de fantasias, etc. A mídia, contudo, privilegia o desfile dos blocos de trio, transmitido ao vivo pela Rede Bandeirantes de tevê desde a década de 1990. A partir de então, uma série de "carnavais fora de época" foi criada em várias cidades do Nordeste, seguindo o modelo de brincadeira soteropolitano, contando com orientação, apoio logístico e cogestão dos empresários e artistas baianos, que literalmente "ensinavam" a fazer trios, montar a estrutura física e midiática da festa e dela participavam com apresentação de vários cantores. Isso não significava a exclusão dos grupos locais: em cada cidade a criação de bandas de axé era estimulada, sendo logo incluídas na programação do evento. Assim, as micaretas tornaram-se um grande negócio, tanto para os baianos quanto para os artistas e agentes culturais locais: elas movimentam a economia, a indústria do turismo e geram diversão e trabalho para a população. Embora muitas tenham encolhido e algumas nem sejam mais realizadas, durante quase 20 anos (de 1990 a 2010) elas marcaram o cenário carnavalesco nordestino. ${ }^{4}$ 
De posse dessas informações é possível considerar que o senso comum faz desses dois carnavais uma ideia bipartida, que leva em conta apenas as duas principais atrações de cada festa (escolas de samba no Rio e blocos de trio em Salvador), em raciocínio tipificante muito redutor: o carnaval carioca seria o maior espetáculo da Terra; o baiano, a maior festa; o primeiro seria discursivo, educativo, cheio de regras; o segundo, descompromissado, prazeroso, mais livre e espontâneo; o carnaval carioca que já foi predominantemente auditivo (devido à importância musical do samba) hoje é visual e contemplativo; o carnaval baiano permanece auditivo (axé music) e é ainda sensorial, tátil, promove mais contato físico (a ordem é "beijar muito!"). Cria-se uma nova mitologia e formulam-se chavões do tipo: "O Rio é para ver, a Bahia para dançar; o Rio é contemplativo, a Bahia é participativa", etc. Como toda dicotomia, regese por antagonismos simplificadores que obliteram a complexidade dos muitos fatores que concorrem para a realização da festa. Deve-se reconhecer que esses dois modelos se imbricam, e isto é visível nas duas festas: passar o carnaval em Salvador não significa liberdade absoluta; assim como no Rio, a busca obsessiva pela perfeição continua restrita aos desfiles do Grupo Especial, pois entre as escolas menores e no carnaval de rua, a situação é outra (ARAÚjo, 2008).

Como segunda mola propulsora da análise, adoto a noção de "campo cultural" de Pierre Bourdieu; segundo o autor, qualquer campo artístico é caracterizado principalmente pela luta, pela competição, uma guerra mais ou menos declarada pela tomada das posições de poder, o que envolve não apenas artistas, mas investidores, patrocinadores e públicos. Estar na "crista da onda" e lançar modas culturais não é apenas questão de talento, mas de conjuntura favorável e aproveitamento de oportunidades:

é a própria luta que faz a história do campo, é pela luta que ele se temporaliza... engendra-se no combate entre aqueles que marcaram época e que lutam para perdurar e aqueles que não podem marcar época sem expulsar para o passado os que têm interesse em deter o tempo, eternizar o presente; entre os dominantes (que compactuam com a continuidade, identidade e reprodução) e os dominados (recém-chegados, interessados na descontinuidade, ruptura, revolução). Marcar época é fazer existir uma nova posição para além das posições estabelecidas, introduzindo diferença, produzindo tempo (BOURDIEU, 1996, p. 181).

As observações de Bourdieu são aplicáveis ao que chamo de "campo do carnaval brasileiro". No nível nacional há uma luta por seu domínio, traduzida hoje principalmente pelo antagonismo entre Rio e Salvador. Por outro lado, em cada cidade, há outra série de conflitos, pelo domínio do campo local. Do 
mesmo autor, aproveito também a noção de capital simbólico, sobre a qual se estabelecem os vários discursos que pleiteiam visibilidade, consideração e investimento. Daí resulta, o que Bourdieu chama de poder simbólico, que, uma vez estabelecido, tende a formar círculos de reprodução e repetição, barrando de certa forma, a renovação dos agentes e dos princípios que regem tais postulados. Isso é muito útil quando se analisa o carnaval brasileiro como embate entre dois "complexos de capital simbólico", um forjado no Rio, outro em Salvador, observando suas estratégias para impor-se nacionalmente. São processos de influência cultural, em que cada centro exportador dos modelos e modas carnavalescos tem seguidores, adeptos e também opositores. No entanto, essa disposição de ver a festa pelo prisma do conflito, ainda não foi totalmente aceita no campo dos estudos do carnaval, como lembra Cunha:

A pergunta que retorna é por que os pesquisadores brasileiros têm se negado a fazer do carnaval um objeto de investigação sistemática com a mesma disposição de crítica e reflexão que têm demonstrado com respeito a outros aspectos (...) como o movimento sindical, o pensamento político ou as formas de atuação do estado (...) essa concepção de cultura tem a ver com antigo esforço de ocultamento daquela que talvez seja a mais original marca da "brasilidade": ausência de direitos, a fragilidade da cidadania, a desigualdade radical, encobertas por um incorrigível populismo nacionalista (CUNHA, 2002, p. 307 e 312).

De qualquer forma, essa tendência vem-se afirmando, e, com a superação do conceito de "festa de inversão" (DAMATTA, 1990), outras vertentes interpretativas começam a impor-se, vendo o carnaval como momento privilegiado de equacionamento de tensões, medição de forças e disputas, tanto diacrônica (acompanhando a "evolução" das brincadeiras) quanto sincronicamente - no nível estrutural (entre os agentes do mesmo grupo), no nível local (entre as brincadeiras de cada cidade) e nacional (entre as festas promovidas em vários centros urbanos), configurando batalhas simbólicas, em que muito está em jogo: o direito de dizer o que é o "verdadeiro carnaval", que tipo de brincadeira atende a essa denominação, as recompensas econômicas e simbólicas por fazer parte da programação oficial (financiada pelo dinheiro público) em cada cidade, o poder de atrair turistas em número crescente, etc.

Em uma perspectiva histórica, alguns estudiosos recentes já verificaram o quanto a dinâmica da festa se deve ao princípio da luta, muitas vezes declarada, entre as brincadeiras que mais se destacavam no cenário carnavalesco. É o que demonstra Cunha sobre o carnaval carioca entre finais do século XIX e início do $\mathrm{XX}$, quando as grandes sociedades procuravam eliminar as brincadeiras do 
entrudo (CUNHA, 2002); Felipe Ferreira (2005) analisa a disputa entre cordões e ranchos.

Outros identificam a hegemonia das escolas de samba carioca com a hegemonia da cidade do Rio de Janeiro sobre a festa nacional. A manifestação foi eleita pelos poderes constituídos como a "mais brasileira" de todas as brincadeiras carnavalescas, transformada em principal atração do carnaval, base sobre a qual se construíram imagem e conceito da "festa nacional" até a década de 1980 (CAVALCANTI, 1999; MOURA, 1986). A hegemonia desses grupos começa a ser questionada em meados dos anos 80 , devido, sobretudo, à sensação de incapacidade de "copiar" de forma eficiente as escolas cariocas e à maior visibilidade do modelo de carnaval baiano - um sucesso local e polo de atração turística desde a década de 1970, mas cujo crescimento massificador dá-se de forma mais importante a partir de meados dos anos 80 (FERREIRA, 2004; CAVALCANTI, 1999).

Dessa forma chegamos à configuração atual do "campo carnavalesco brasileiro", uma disputa cada vez mais clara entre as maiores festas realizadas nas cidades do Rio de Janeiro, Salvador e Recife. Ao mesmo tempo, em cada uma dessas cidades há uma série de disputas internas entre as brincadeiras pela melhor colocação dentro do campo local: em Salvador entre blocos afro, blocos de trio e afoxés; no Rio de Janeiro entre escolas de samba maiores e menores, blocos de embalo, blocos de clóvis; em Pernambuco, primeiramente entre Recife e Olinda, e mais especificamente na primeira, entre maracatus de baque solto, de baque virado, escolas de samba, caboclinhos e blocos de todos os tipos.

Um dos meios de medir o prestígio de um centro cultural é observar o quanto suas propostas são "copiadas", adaptadas, propagadas, num processo de reafirmação do capital simbólico, discurso monocórdio que requer resposta em forma de coro. Tais influências - antes vistas como ameaçadoras apenas quando provinham de países externos - agora geram respostas hostis dentro do próprio país, cada cidade tentando impor e visibilizar sua identidade local como "melhor, mais aprazível e recompensadora". O fenômeno da xenofobia, antes direcionado para o estrangeiro, regionalizou-se: uma região teme a força cultural da outra (IANI, 1997). O carnaval brasileiro pode ser compreendido dentro desse contexto de jogo simbólico.

Adotando o modelo da teoria da dependência (SANTOS, 2000) talvez seja possível falar em processos sucessivos de colonização e descolonização do carnaval brasileiro, do ponto de vista da influência carioca (entre 1950 e meados de 1980) e do ponto de vista da influência soteropolitana e 
recifense (sobretudo a partir de 1990). Segundo Caldeira, as sociedades de capitalismo subdesenvolvido mantêm em seu interior centros dinâmicos, que exercem influência e hegemonia sobre centros menos dinâmicos, "sociedades reflexas" ou periféricas. Na sociedade brasileira existem centros mais dinâmicos, localizados na Região Centro-Sul, em que predomina e se configura o capitalismo avançado do país, em contraste com as demais regiões, em que predominam formas socioeconômicas tipificadoras de uma sociedade tradicional. O capitalismo dependente gera, ao mesmo tempo, o subdesenvolvimento econômico, social, político e também cultural. Citando Fernando H. Cardoso e Florestan Fernandes, Caldeira lembra:

A dependência é um sistema herdado do passado colonial... as sociedades periféricas passaram a engendrar e a desenvolver processos sociais cuja explicação se encontra intimamente vinculada à sua situação de dependência. Diversamente do período colonial, quando eram fornecedoras de matéria-prima, a transformação das ex-colônias (sociedades periféricas) passou a se relacionar à incorporação de elementos exógenos, produzidos nas ex-metrópoles, engendrando novas formas de dependência, em que a periferia jamais pode dinamizar autonomamente os seus processos produtivos, sem alterar o caráter estrutural da dependência. Entretanto a Teoria da Dependência procura investigar as contradições geradas por esse fenômeno, evidenciando que a relação dominação/subordinação possui aspectos mais complexos. As estruturas dependentes não podem ser concebidas como meramente reflexas: ao contrário têm uma dinâmica própria dentro dos limites definidos pelas relações de dominação. O capitalismo dependente estabelece conexões entre os mais variados setores das sociedades inclusivas, gerando ao mesmo tempo subdesenvolvimento econômico, social, cultural e político (CALDEIRA, 1976, p. 6-9).

No caso do carnaval, pode-se observar, de fato, essa relação de dependência. Algumas cidades se prodigalizam como principais centros realizadores da festa, forjando modelos depois disseminados através da mídia para outras. Até a década de 1980 a cidade-modelo exportadora era o Rio de Janeiro (QUEIRós, 1990). A partir de meados da década de 1980 outras cidades, dessa vez da Região Nordeste (Salvador, Recife e Olinda), tornamse centros disseminadores de novos modelos da festa, e muitas capitais do Nordeste começam a adaptá-los para suas realidades locais. Nesse processo, considerando a possibilidade de invenção de novas tradições carnavalescas ou resgate de brincadeiras que reforçassem as identidades locais, as escolas de samba perderam espaço, pois ainda são muito identificadas com a festa 
carioca. A música baiana carnavalesca (axé music) é o hino do carnaval brasileiro atual, título que já foi do samba-enredo. Em muitas cidades isso determinou o desaparecimento e/ou encolhimento das agremiações identificadas com o carnaval carioca. Na falta de melhor expressão, chamarei esse processo de "retração das escolas de samba", apresentando aquilo que Geertz denomina "dados convergentes" ${ }^{5}$ sobre o carnaval em três capitais da região meionorte brasileira. Já vimos o que se deu em São Luís. Vamos agora para Belém e Teresina. ${ }^{6}$

\section{OUTROS CARNAVAIS: BELÉM E TERESINA}

No início da década de 2000 comecei a verificar o processo de desaparecimento das escolas de samba no interior do Maranhão. Percebi então que o fenômeno se repetia em parte do Norte e do Nordeste: das capitais vizinhas (Teresina e Belém) chegavam notícias semelhantes - durante a década de 1990 muitas escolas de samba haviam encolhido drasticamente.

Em Teresina, as escolas de samba ficaram sem desfilar de 1993 a 1997 porque lhes foi retirado todo e qualquer apoio financeiro e logístico - só conseguiram reobter o direito aos subsídios e ao desfile depois de um movimento político-cultural organizado. Um agente cultural local apresenta uma visão crítica do ocorrido:

No início dos anos 90 havia mais de 20 grupos brigando pela subvenção da prefeitura. Eram caricaturas de escola de samba brigando pelo dinheiro público - e cada vez surgiam mais escolas à custa da prefeitura. E começaram a surgir várias denúncias de mau uso do dinheiro. Então o prefeito Heráclito deu um basta. O povo diz que ele "acabou com o carnaval", mas eu não acredito nisso: o prefeito não é dono do carnaval. Ele apenas tirou a subvenção por conta da desordem total. A Bahia, por exemplo, apostou no carnaval empreendedor e a coisa cresceu. Com as escolas isso não aconteceu. E hoje continua a mesma coisa: as escolas voltaram a desfilar, mas não se autossustentam. ${ }^{7}$

Com a retração das escolas de samba, dão-se o surgimento e o crescimento de outras manifestações ligadas ao "carnaval de rua", como bandas, blocos alternativos e especialmente blocos afro, que cresceram muito nesse período (MONTEIRO, 2008). Os amantes do samba passaram a brincar o carnaval na cidade de Barras, cuja prefeitura ainda apoiava a manifestação. Wellington diz que "hoje quase todas as cidades se converteram ao carnaval baiano: é mais barato de fazer, chama mais turismo e dá mais lucro". Ainda em sua opinião, embora haja um discurso sobre a identidade local, o "piauilismo", 8 isso não foi 
preponderante para o abandono das escolas. Ao mesmo tempo em que elas se retiravam da cena, promovia-se a Micarina (micareta de Teresina), inicialmente no mesmo espaço de desfile daquelas, a Av. Frei Serafim, e depois transferida para espaço fechado.

Em Belém, apesar de o número total de agremiações não ter diminuído drasticamente e da construção do sambódromo em 2000, as escolas perderam desfilantes e público. ${ }^{9}$ E ali o discurso da afirmação identitária parece ter contribuído para tal:

O Pará não conseguiu forjar um produto turístico vendável como São Luís e outros locais. Belém tem dois milhões de habitantes, mas falta isso. A identidade cabocla sempre foi desprezada. Outros locais fizeram investimentos no caboclo enquanto símbolo, como Parintins, mas Belém não. Perdemos tempo e agora eles [o pessoal do governo] querem um tipo de produto genuinamente caboclo, feito às pressas: querem fazer desfile de barco, querem substituir baiana por tacacazeira... E escola de samba não combina com isso, elas não se prestam a esse objetivo, são referencializadas no Rio, não querem saber de cultura local. Chegaram a tentar transformar as escolas em algo parecido com o boi de Parintins (2003), mas não deu certo, não funcionou, era uma preocupação dos gestores, de cima pra baixo... ${ }^{10}$

Também em Belém observa-se a chegada das micaretas, entretanto sem igual sucesso. No entanto, conflitos políticos entre o PT e o PSDB, dos quais as escolas participaram ativamente, e os novos produtos da cultura local, como o ritmo calipso e a presença das "aparelhagens" (equipes de som, como as de funk no Rio, só que tocando o "tecnobrega"), contribuíram para o afastamento das escolas de samba. Rodrigues (2006) resume:

O ápice do carnaval das escolas foi a década de 1980, quando prefeitura e governo do estado eram do mesmo partido (PMDB). Não tinha sambódromo, mas eles se juntavam e faziam uma superestrutura. A subvenção era bem maior, as escolas levavam três mil brincantes, cinco alegorias, traziam puxadores do Rio, etc. Tinha investimento. Depois que os governantes passaram a ser de partidos diferentes, a coisa caiu: há uma rixa política, teve um ano com duas ligas, dois desfiles diferentes, dividiu muito. E depois tem as aparelhagens, que tocam todos esses ritmos populares, atraem muita gente. Qualquer evento que você faça, está concorrendo com elas. As festas são altamente rentáveis porque é só play-back, eles não têm muita despesa. 
Tanto em Belém quanto em Teresina, as novas classes médias elegeram como principal programa de carnaval viajar para as cidades do litoral, esvaziando os centros urbanos e provocando a falência do "carnaval dos salões" dos clubes sociais - antes programa obrigatório. Em São Luís, que já é uma ilha, o êxodo se dá em direção às cidades do interior. Em 2011 passei o carnaval em Belém, observando a dinâmica da festa. Só havia movimento na Aldeia Cabana, nome dado ao sambódromo, que está mal conservado e não consegue atrair o público de classe média. Nesse ano, várias das grandes escolas não desfilaram, entre elas o Rancho Não Posso me Amofiná, a maior e mais famosa delas, desfalcando o desfile por motivos políticos. O desfile também carecia de maior organização: o horário estabelecido não foi cumprido, não havia punições previstas para tais casos, e as últimas escolas desfilaram para arquibancadas e camarotes quase vazios. Enquanto isso, o Centro de Belém, antes movimentado, não sabe mais o que é carnaval. Também não identifiquei planos sobre uma possível "revitalização" do carnaval de rua de Belém, mas sim um esforço cada vez maior em "descentralizar a festa", oferecendo programação carnavalesca em vários bairros da cidade.

\section{CARNAVAL, TURISMO, REGIONALISMO E LUCIDEZ COLETIVA}

Muitos fatores parecem contribuir para a convergência desses processos - tanto o discurso identitário quanto a exportação do carnaval baiano e a comparação da rentabilidade (econômica, política, simbólica) dos vários modelos de festas e produtos de entretenimento. O discurso identitário incrementa-se com os investimentos oficiais na área do turismo cultural, com destaque para as capitais do Nordeste, cujos agentes começam a organizar suas atividades em função do calendário turístico, baseados na ideia de cultura como expressão de uma identidade regional distinguível. ${ }^{11} \mathrm{O}$ regionalismo professado hoje por muitos agentes culturais nordestinos tem relação direta com o sucesso de outros movimentos culturais como a Tropicália (Salvador/Rio, década de 1970), o renascimento do frevo e do forró (Recife/Olinda, Campina Grande/ Caruaru/João Pessoa/Fortaleza, década de 1980) e o mangue-beat (Recife, década de 1990). Em muitas cidades, os agentes culturais locais seguiram o exemplo, buscando em seu próprio repertório cultural, produtos "originais", que os diferenciassem, na tentativa da construção de uma identidade cultural "única e irrepetível", capaz de atrair pelo ineditismo, a atenção da mídia e dos turistas. ${ }^{12}$ Em São Luís o destaque foi dado às brincadeiras folclóricas juninas, 
como o bumba meu boi e às formas arcaicas do samba, como o tambor de crioula.

Nas capitais do Nordeste os agentes culturais têm respondido de maneira muito prática às questões colocadas hoje pelo carnaval, sendo a mais importante a opção pelo modelo de festa a ser adotado, o carioca, baiano ou pernambucano, dilema que toda cidade enfrenta hoje ao organizar suas festas carnavalescas: "Que tipo de carnaval vamos realizar? Um carnaval "tipo carioca" ou "tipo baiano"? Isso não era comum até o início da década de 1990, quando praticamente todo o Brasil tentava copiar o modelo carioca sem maiores hesitações, prova incontestável de sua hegemonia. Hoje, muitas cidades acabam optando pelo modelo baiano, numa estratégia de substituição, que consome todos os investimentos disponíveis, deixando os grupos sambistas à margem do processo de captação de recursos, inviabilizando sua participação na festa e induzindo ao desaparecimento.

A opção pelo carnaval baiano é justificada de muitas formas pelos agentes que produzem, financiam e brincam o carnaval: para o folião é uma festa "mais livre e prazerosa"; ${ }^{13}$ para os produtores e patrocinadores, com maior apelo midiático e mais lucrativa - imbricada que está com o mundo do showbussines, marcado pela transformação de produtos culturais em produtos de um mercado que extrapola o próprio carnaval como festa demarcada pelo calendário tradicional, multiplicando-se em muitos "carnavais fora de época", maximizando a possibilidade de lucros. ${ }^{14} \mathrm{O}$ produto "carnaval baiano" é considerado mais adequado aos processos de transposição, gerando níveis de lucro e satisfação estética mais altos nas cidades para as quais foi levado.

Outro importante efeito dessa mudança no cenário carnavalesco da região meio-norte brasileira é que, com a retração das escolas de samba, diminuem também a visibilidade e o poder de negociação dos grupos mantenedores das agremiações. Quase sempre, em todas as cidades em que se disseminam, as escolas de samba são forma de diversão e afirmação cultural da população urbana negro-mestiça e periférica configurando-se como importante estratégia de exibição social, organização de movimentos comunitários, oportunidade de trabalho social e político-partidário e/ou idealista, bem como canal privilegiado para emissão de discursos e interpretações críticas sobre a realidade, através da escolha e do desenvolvimento dos enredos anuais, bem como de um discurso estético específico. Tudo isso está em jogo na construção e manutenção de uma agremiação sambista. Nas cidades observadas há exemplos de agremiações que reúnem muitas dessas variáveis: é o caso do Rancho Não Posso me Amofiná, em Belém, verdadeiro porta-voz da comunidade do Jurunas 
- bairro popular marcado por uma série de problemas sociais e urbanos; o caso da Turma do Quinto em São Luís, que com sua proposta regionalista deflagrou a pesquisa sobre uma estética "maranhense" no nível das artes visuais (na década de 1980 já fez a opção pelo trabalho com artesanato local e fibras naturais); ou ainda o caso das escolas de Teresina, que se organizaram coletivamente para exigir do poder público a volta dos desfiles oficiais na capital. Em todos esses exemplos fica patente a existência de processos de consciência e alto grau de lucidez coletiva, como diria Duvignaud:

Os Estados, quer representados por um príncipe, um ditador ou um todo-poderoso delegado, quer encarnando-se em uma força abstrata e administrativa, resistem à materialização de dimensões coletivas e espontâneas de poderio e combatem a festa. Porque nenhum Estado pode, sem reação, admitir que os homens se agrupem segundo um 'nós' que, através da sua própria concentração, afirme o seu desejo de autogestão e assim não concorde em assistir ao seu poder sublimado em ' 'Estado'. Pois tais extensões libertárias se recompõem ao sabor das praças e dos campos (...) Certamente, a partir do momento que uma aglomeração destas adquire a consciência particular de um 'nós' ativo e diferente do resto da sociedade não podemos visualizá-la como multidão ou como massa, mas, ao contrário, nela vemos um grupo dotado de uma lucidez coletiva direcionada para uma ação comum. Nada é mais impressionante como assistir ao desenrolar deste gênero de manifestação (DUVIGNAUD, 1983, p. 167).

Um carnavalesco com quem conversei em Teresina apresenta sua visão crítica do assunto, em total acordo com Duvignaud:

Nesse negócio de micareta é mais fácil para esses prefeitos de cidade pequena fazer negociatas: eles contratam os trios, dizem que foi tanto, pagam a metade, botam outro tanto no bolso e fica tudo por isso mesmo. O povo nem quer saber. Se vem Ivete Sangalo, Banda Cheiro, Asa de Águia, tá tudo bem. Com as escolas de samba é mais difícil, tem que fazer muitas reuniões, discutir isso, discutir aquilo, atender às reivindicações, dividir a verba por igual na frente de todos, é um monte de problema. Tem problema antes, tem problema durante o desfile e depois, com a apuração dos resultados. Eles não querem mais isso. Por isso as escolas de samba estão acabando. ${ }^{15}$

Quero indicar que quando um carnaval de modelo sambista, cuja celula mater é a escola de samba, gerida quase sempre por grupos populares de negros-mestiços, é substituído por outros modelos - carnaval de trio e de blocos não dramáticos, com maior acento no apelo comercial e lucrativo, gerenciados 
de cima para baixo, de fora para dentro, por grupos especializados da indústria cultural e do entretenimento - verifica-se um acentuado deslocamento do poder de manipulação da festa e das recompensas materiais e simbólicas que ela pode trazer. O que o carnavalesco chama de "discussão de problemas" pode ser aproximado do sentido de visão crítica da realidade e do papel do Estado, da noção de projeto, do acompanhamento e fiscalização de sua realização, da avaliação e julgamento posterior de como tudo aconteceu - a lucidez coletiva citada por Duvignaud. Se no Brasil a população ainda tem dificuldades de fazer isso em relação aos principais papéis do Estado (segurança, saúde, educação), me parece que no carnaval, com atuação das escolas de samba e outros grupos organizados, essa cogerência das responsabilidades chega mais perto de se tornar realidade.

\section{REFERÊNCIAS BIBLIOGRÁFICAS}

ARAÚJO, Eugênio. Não deixa o samba morrer: um estudo histórico e antropológico sobre o carnaval de São Luís e a escola Favela do Samba. São Luís: Edufma, 2001.

Valorizando a batucada: um estudo sobre as escolas cariocas dos grupos de acesso $C$, $D$ e E. Tese de doutorado. Programa de Pós-graduação em História da Arte, EBA/UFRJ, 2008.

BANDUCCI JR., Álvaro \& BARRETO, Margarita (orgs.). Turismo e identidade local: uma visão antropológica. Campinas: Papirus, 2001.

BOURDIEU, Pierre. As regras da arte. São Paulo: Companhia das Letras, 1996.

BRITO, Nelson. O carnaval da cara de São Luís ou a volta do filho pródigo. Vagalume - suplemento cultural do Sioge. São Luís: Sioge, 1990, p. 26.

CALDEIRA, José de Ribamar. Mudanças sociais no Maranhão. São Luís: paper, 1976.

CAVALCANTI, M.L.V.C. O rito e o tempo: ensaios sobre carnaval. Rio de Janeiro: Civilização Brasileira, 1999.

CUNHA, Maria. Clementina Pereira (org). Carnavais e outras $f(r)$ estas: ensaios de história social da cultura. Campinas: Editora da Unicamp/Cecult, 2002.

DAMATTA, Roberto. Carnavais, malandros e heróis. Rio de Janeiro: Guanabara/ Koogan, 1990.

DUVIGNAUD, Jean. Festas e civilizações. Fortaleza/Rio de Janeiro: Edufe/ Tempo Brasileiro, 1983.

ECO, Humberto et al. Carnaval! Mexico: Fondo de Cultura Economica, 1989.

FERREIRA, Felipe. O livro de ouro do carnaval brasileiro. Rio de Janeiro: Ediouro, 2004.

. Inventando carnavais: o surgimento do carnaval carioca no séc. XIX e outras questões carnavalescas. Rio de Janeiro: EDUFRJ, 2005. 
GEETRZ, C. Saber local. Petrópolis: Vozes, 1997.

HOBSBAWM, Eric J. Nações e nacionalismo desde 1870. Rio de Janeiro: Paz e Terra, 1990.

IANI, Otávio. A era do globalismo. Rio de Janeiro: Civilização Brasileira, 1997.

KUMAR, Krishan. Da sociedade pós-industrial à pós-moderna. Rio de Janeiro: Zahar, 1997.

MONTEIRO, Artemisa Odila Cande. O processo de construção da identidade negra em Teresina: o caso do grupo afrocultural Coisa de Nêgo. Dissertação de mestrado. Programa de Pós-graduação em Estudos Étnicos e Africanos, do Centro de Estudos Afro-Orientais. Faculdade de Filosofia e Ciências Humanas, Universidade Federal da Bahia, 2008.

MOURA, Milton Araújo. Carnaval e baianidade: arestas e curvas na coreografia de identidades do carnaval de Salvador. Tese de doutoramento. Programa de Pós-graduação em Culturas Contemporâneas da Faculdade de Comunicação da UFBA. Salvador, 2001.

MOURA, Roberto M. Carnaval: da redentora à Praça do apocalipse. Rio de Janeiro: Zahar, 1986.

OLIVEIRA, Sérgio Ricardo Góes. O comportamento do consumidor e as estratégias de marketing: o caso de duas empresas gestoras de blocos de trio do carnaval baiano. Dissertação de mestrado. Escola de Administração da Universidade Federal da Bahia, Salvador, 2001.

QUEIRÓS, Maria Isaura Pereira. Carnaval brasileiro: o vivido e o mito. São Paulo: Brasiliense, 1990.

RODRIGUES, Carmem Izabel. Vem do bairro do Jurunas: sociabilidade e construção de identidades entre ribeirinhos em Belém/PA. Tese de doutorado. Programa de Pós-graduação em Antropologia, UFPA, Belém, 2006.

RODRIGUES, João Jorge. É preciso pensar o carnaval no âmbito da cidade. In Seminários de Carnaval II. Pró-reitoria de Extensão/UFBA. Salvador, 1999.

SANTOS, Theotônio dos. A teoria da dependência. Rio de Janeiro: Civilização Brasileira, 2000.

TRAMONTE, Cristina. O samba conquista passagem: as estratégias educativas das escolas de samba. Petrópolis: Vozes, 2001.

\section{NOTAS}

1 "Os carnavais de maior destaque no cenário nacional são aqueles que apostaram na sua identidade cultural. Rio de Janeiro, Salvador e Recife são exemplos de carnavais que encontraram seu próprio caminho. O nosso objetivo, através de um carnaval de rua 'de primeira', é garantir a inclusão da cidade no roteiro dos grandes e concorridos carnavais. Carnaval de rua! Este sim tem a cara da gente: espontâneo, criativo, democrático e superdivertido. Um evento popular de identidade própria que tem graça, originalidade, conteúdo e tradição". (BRITO, 1990, p. 26) "O Secretário de Cultura Luís Phelipe Andrés lançou oficialmente no último dia 19 de janeiro o Plano de Apoio ao Carnaval de Rua de São Luís. O 
plano beneficia as diferentes brincadeiras que vêm alegrando nosso carnaval de rua: corsos, bandas, casinha da roça, tambor de crioula, tribos de índios, blocos organizados, bloco de ritmo e escolas de samba (exceto as que concorrem em desfile de passarela). A Secma [Secretaria de Cultura do Estado do Maranhão] pretende com essa iniciativa contribuir para a dinamização do carnaval enquanto brincadeira espontânea e livre, sem todo conjunto de normas e pré-requisitos que caracterizam os desfiles de passarela, os quais têm reduzido a festa a um espetáculo com hora marcada e local fixo." Secma apoia carnaval de rua. Azulejos: informativo da Secretaria de Estado da Cultura. São Luís: Secretaria de Cultura, jan./fev., 1993, p. 08. (grifo meu) Notar que os dois discursos correspondem a posições de agentes oficiais dos órgãos de cultura local: embora neste momento, Nelson Brito ainda fale como agente cultural, em 1992, chegaria a presidente da Fundação Cultural do município e implementaria oficialmente sua visão regionalista da festa.

2 Entrevista com José de Ribamar Moraes Silva, ex-dirigente da GRES Pirata do Samba. Apud Santos, Herbert de Jesus. Escolas de samba extintas e sepultadas. Vagalume: Suplemento Cultural do Sioge. São Luís, março-abril, 1994, p. 27. Na mesma reportagem o autor lista as escolas extintas, no total de 21 agremiações. Dessas, apenas duas voltaram a desfilar.

3 Sobre esse ponto v. Tramonte, 2001. Especialmente a Parte II:“As estratégias e a ação educativa das escolas de samba", em que a autora, com base em estudo sobre as escolas de samba de Florianópolis, desenvolve a ideia de várias "práxis pedagógicas" presentes no processo de criar, manter e organizar o desfile anual de uma agremiação. Seriam "processos pedagógicos", tais como: pedagogia da ação social, da ação política, dos valores éticos e morais, da ação escolar e da arte. Além disso, o estudo é importante quando demonstra que também nas cidades sulistas, as escolas de samba vêm sofrendo ataques do tipo já mencionado.

4 Em São Luís, por exemplo, o Marafolia que aconteceu durante 13 anos na Avenida Litorânea (área nobre da cidade), foi transferido a partir de 2009 para o Centro da cidade, ocorrendo hoje no mesmo espaço em que desfilam as escolas de samba (e que é considerado "popular"), já não com desfile de trios, mas sob a forma de "maratona de shows". Os ingressos baratearam, o público mudou, mas ainda assim é evento que movimenta a cidade. É tendência em várias cidades que as micaretas deixem de ocupar grandes espaços públicos abertos e passem a ser realizadas no sistema indoor.

5 Dados convergentes seriam fatos fora do comum, que são coletados em momentos oportunos e retratados de várias formas e que apesar disso, têm a capacidade de elucidar-se mutuamente, simplesmente porque as vidas dos indivíduos que eles descrevem, medem ou observam, têm uma forte conexão entre si. (...) Na antropologia, o foco em comunidades naturais, grupos de pessoas que estão ligadas entre si de múltiplas maneiras, possibilita a transformação daquilo que parece ser apenas uma coleção de material heterogêneo em uma rede de entendimentos sociais que se reforçam mutuamente" (GEERTZ, 1997, p. 234).

6 Tenho feito frequentes viagens a essas duas capitais, conversado e entrevistado vários agentes ligados à política cultural e ao carnaval. Além disso, efetuo pesquisa 
histórica nas bibliotecas locais, consultando os periódicos que costumam apresentar anualmente toda a programação da festa e repercutir os principais problemas. Em 2011 passei o carnaval em Belém acompanhando a festa de perto.

7 Entrevista com Wellington Sampaio, artista plástico e ativista cultural. Teresina, 2007. Em meados da década de 1990, um jornal descreve as festas carnavalescas na cidade, em que se percebe a influência carioca, mas não através do samba: "A presença de funkeiros e animação de jovens acostumados mais com rock do que samba e a apresentação do bloco afro Coisa de Nêgo, marcaram os quatro dias do carnaval de Teresina, dado como decadente (...) Excluídas há dois anos do carnaval de Teresina, as escolas de samba levaram um grupo de crianças e carnavalescos para a avenida com faixas de protesto contra a organização feita pela Secretaria Municipal de Esportes e Lazer de Teresina. O secretário municipal de Esportes e Lazer, Fernando Said, disse que o principal problema é que "as escolas de samba, que poderiam abrilhantar o carnaval, não se organizam e com isso o carnaval perde um pouco. A secretaria mais uma vez está disposta a trabalhar com as escolas na organização do carnaval. Só que isso não pode ser feito em cima da hora' - acrescentou". Efrém, Ribeiro. Funkeiros mudam carnaval de rua na Frei Serafim. O Dia. Teresina, 02/03/1995, p. 4.

8 Movimento cultural baseado na valorização dos aspectos regionais do Piauí; no Maranhão esse movimento vem tomando o nome de "maranhensidade". A estranheza dos nomes não deve enganar: em ambos os estados eles têm como alvos preferenciais de ataque determinados produtos culturais identificados com outras realidades, como a escola de samba. Sua atuação é fortemente sentida no plano das políticas culturais oficiais, já que muitos de seus agentes participam das máquinas administrativas do estado e município.

9 Através dos jornais é possível acompanhar essa trajetória: em 1985 desfilaram 13 escolas de samba (divididas em grupos A, B e C); o palco da festa em Belém, ainda uma passarela desmontável, oferecia oito mil lugares na arquibancada e mais 235 camarotes e "somente com a venda de ingressos a prefeitura espera arrecadar 500 milhões de cruzeiros, enquanto o investimento total foi 350 milhões". Cf. Província do Pará, Belém, 02/02/1985, p. 4. Dez anos depois, em 1995 , desfilaram nove escolas no grupo A e quatro no grupo B, mas a passarela desmontável oferecia apenas 64 camarotes. Cf. O Liberal, Belém, 25/02/1995, p. 10. Obs: o número de lugares nas arquibancadas não constava na reportagem. Entre 1985 e 1995 o número de agremiações manteve-se estável (13). Em 2000, desfilaram sete escolas no grupo A e 14 no grupo B; apesar de o número de escolas ter aumentado, os desfilantes diminuíram: enquanto nos anos 80 as maiores escolas levavam cerca de três mil pessoas à avenida, no início do milênio cada escola do grupo A contava com mais ou menos 1.200 componentes. E o público presente a cada noite de desfile no sambódromo recém-inaugurado foi de apenas 4.100 pessoas. Cf. O Liberal. Belém, 08/03/2000, p. 12.

10 Entrevista com a professora doutora Carmem Izabel Rodrigues, autora da tese Vem do bairro do Jurunas: sociabilidade e construção de identidades entre ribeirinhos em Belém/PA. Programa de Pós-graduação em Antropologia, UFPA, Belém, 2006. Segundo a autora o bairro destaca-se por intensa produção cultural, 
congregando ainda em seu bojo uma das maiores e mais tradicionais escolas de samba da cidade, o Rancho Não Posso Me Amofiná.

11 “... o texto da baianidade é mais nítido na burocracia governamental e no empresariado do turismo. Convém atentar para a maneira como se veicula a produção deste discurso no material de propaganda da Bahiatursa, órgão estadual do turismo. Com a sua fundação, em 1968, o turismo já se apresenta como umas das prioridades do planejamento estadual: até 1979 tratou-se de dotar o setor de uma infraestrutura digna deste nome; entre 1979-86 o governo procurou captar o maior número de turistas nacionais e estrangeiros; no período de 1991-99 a Bahia passa de oitavo a segundo polo turístico brasileiro" (MOURA, 2001, p. 169).

12 Sobre nacionalismo e regionalismo v. Hobsbawm, 1990 e lani, 1997; sobre a influência do turismo na dinâmica cultural v. Kumar, 1997 e Banducci e Barreto, 2001.

13 "Um outro aspecto unânime que influencia na decisão de compra do consumidor do produto Bloco de Trio do carnaval de Salvador é a questão da liberalidade. É de domínio público a existência da liberação de libido durante os festejos carnavalescos, sejam eles em Salvador ou em qualquer outro lugar. Entretanto, o que o público entrevistado sustentou é que existe uma maior facilidade de se 'ficar' ou se relacionar dentro dos blocos de trio. Essa facilidade em algumas entrevistas foi colocada no sentido sexual. A questão sexual está muito presente nos grupos de turistas entrevistados e é um fator citado por muitos executivos como sendo causa de alguns abusos que geram violência dentro dos blocos de trios" (OLIVEIRA, 2001, p. 63).

14 "Somente nas maiores capitais e cidades há dezoito carnavais fora de época no Brasil, organizados pelas prefeituras e empresas privadas. Hoje as micaretas estão dominadas por cinco ou seis grupos. Economicamente as micaretas dão dinheiro, dão lucro. Os grupos que dominam são basicamente o Chiclete com Banana, Netinho, Asa de Águia e Banda Eva - grupos menores se inserem uma vez ou outra. Mas não há micareta sem o Chiclete com Banana, é ele quem diz quem vai participar ou não" (RODRIGUES, 1999, p. 65). Notar que em 2008, quase dez anos depois, o Chiclete com Banana mantém sua posição de "mandante" nas micaretas, enquanto muitos novos grupos já participaram do evento.

15 Entrevista com carnavalesco da Escola de Samba Sambão. Teresina, 2006.

Eugênio Araújo é doutor e mestre pelo Programa de Pós-graduação em Artes Visuais, EBA/UFRJ, professor do Departamento de Artes da UFMA, artista plástico e carnavalesco com atuação nas escolas de samba de São Luís, Maranhão. Nas escolas de samba cariocas já colaborou como artesão montador de alegorias e figurinista. 